\title{
RESEARCH PAPER \\ Plant nutrition, foliar standards, chlorophyll activity and soil nutrient status of two cultivars of Leucospermum cordifolium (Proteaceae)
}

\author{
Carlos E. Álvarez, Marino Fernández-Falcón, and M. Mercedes Hernández \\ Instituto de Productos Naturales y Agrobiología, Consejo Superior de Investigaciones Científicas. Avenida \\ Astrofísico Francisco Sánchez 3, La Laguna, 38206. Tenerife, España.
}

\begin{abstract}
C.E. Álvarez, M. Fernández-Falcón, and M.M. Hernández. 2012. Plant nutrition, foliar standards, chlorophyll activity and soil nutrient status of two cultivars of Leucospermum cordifolium (Proteaceae). Cien. Inv. Agr. 39(1): 105-116. Two cultivars ('Succession II' and 'Tango') of Leucospermum cordifolium were studied over three years in commercial plantations with optimum yields located on subtropical La Palma Island (Canarian Archipelago). Four foliar samplings were taken per year to determine the evolution of the $\mathrm{N}, \mathrm{P}$, and $\mathrm{K}$ contents over time and to determine the optimal month for foliar standard sampling. Foliar chlorophyll activity and the foliar standard concentrations of macro- and micronutrients were determined. Soil samples were also taken. Both cultivars developed well in soils with acid and slightly acid $\mathrm{pH}$, low and high organic matter content, and in some cases, high available P concentrations, though Proteaceae is generally considered P sensitive. Chlorophyll activity correlated neither with foliar nutrient levels nor with leaf greenness. The foliar $\mathrm{N}$ content reached a maximum of $17.0 \mathrm{~g} \mathrm{~kg}^{-1}$ in the cultivar 'Succession II' and $17.2 \mathrm{~g} \mathrm{~kg}^{-1}$ in 'Tango', whereas the maximum $\mathrm{P}$ and $\mathrm{K}$ levels were lower in 'Tango' than in 'Succession II'. The greatest stability of the concentrations of these nutrients occurred in September; therefore, this month was chosen for performing foliar standard sampling. The standard ranges of $\mathrm{N}, \mathrm{K}, \mathrm{Ca}$ and $\mathrm{Mg}$ were higher in 'Succession II', while Fe, Mn, and $\mathrm{Zn}$ were higher in 'Tango'. The $\mathrm{P}$ and $\mathrm{Cu}$ standard ranges were similar in both cultivars.
\end{abstract}

Key words: Leaf analysis, protea, 'Succession II', 'Tango'.

\section{Introduction}

Some plants in the protea family (Proteaceae) have reached an increasing interest in the market of cut flowers, where they obtain high prices. Proteaceae are able to grow in poor soils ranging from acidic to neutral pH (Claassens, 1981; Silber et al., 1998).

Received September 22. 2010. Accepted July 18, 2011. Corresponding author: carlose@ipna.csic.es
Soil $\mathrm{pH}$ affects both the development of the roots and their nutrient uptake. The $\mathrm{pH}$ directly affects nutrient availability, as it changes the redox states of each element, making it more or less available to the plant; this, in turn, affects the physical development of the roots. Proteaceae are also able to withstand very low levels of organic matter (Witkowski, 1989). Their phosphorus (P) needs and their sensitivity to high concentrations of this element in the soil depend upon the genus and the species (Handreck, 1991; Buining and Cresswell, 
1993; Montarone and Ziegler, 1996). If the $\mathrm{P}$ content of the soil is low, Proteaceae form dense clusters of roots named proteoid roots that decrease or are eliminated when P levels increase (Shane et al., 2008; Hue, 2009). The maximum concentration of soil-extractable $\mathrm{P}$ in protea-growing areas reported by Parvin (1986) was $25 \mathrm{mg} \mathrm{kg}^{-1}$, although Maier et al. (1995) observed normal protea yields at a site with a soil $\mathrm{P}$ concentration of $64 \mathrm{mg} \mathrm{kg}^{-1}$. Proteaceae also prefer low levels of available cations. Jamienson (1985) recommended Ca values under $6.2 \mathrm{cmol}_{(+)}$ $\mathrm{kg}^{-1}, \mathrm{~K}$ values under $1.0 \mathrm{cmol}_{(+)} \mathrm{kg}^{-1}$, and $\mathrm{Mg}$ values under $1.2 \mathrm{cmol}_{(+)} \mathrm{kg}^{-1}$. Cecil et al. (1995) and Maier et al. (1995) confirmed that proteas require low $\mathrm{K}$ levels to achieve optimum growth. Claassens (1981) observed that many species of proteas tolerate high salt concentrations as long as the levels of other nutrients such as nitrates and phosphates are not high. Rodríguez-Pérez et al. (2001) found that Protea obtusifolia was moderately tolerant to soil salts, with a tolerance threshold of $6.0 \mathrm{dS}$ $\mathrm{m}^{-1}$ of electrical conductivity in the soil saturated extract. Leucospermum cordifolium, by contrast, could tolerate only $1.0 \mathrm{dS} \mathrm{m}^{-1}$.

In 1986, Prasad and Dennis emphasized the scarcity of information on the nutritional needs of Proteaceae. Fifteen years later, Montarone (2001) insisted that this information was still insufficient. This is understandable in light of the fact that nutrient needs of Proteaceae differ by genus and even by species (Claassens, 1986; Montarone et al., 2003). The latter authors studied the nutrition requirements of the genera Protea and Leucospermum and found that Leucospermum has a mineral uptake rate twice that of Protea. In addition, Leucospermum needed high quantities of $\mathrm{K}$ relative to $\mathrm{N}$ (its $\mathrm{K} / \mathrm{N}$ ratio was 1.6), whereas that of Protea was close to 1. Hernández et al. (2008) and González et al. (2008) observed remarkable differences in the nutrition and nutrient distribution of flowering stems within cultivars of the same species. Important nutrients such as $\mathrm{P}$ can cause toxicity effects in Proteaceae (Nichols, 1983; Prasad and Dennis, 1986; Corbella, 2008) because these plants are very sensitive to this nutrient concentrations. Thomas (1980) found that the genus Leucospermum withstands higher P levels than do the genera Banksia, Leucadendron, Protea and Telopea. The remark of Silver et al. (1998) that studies on the effects of other nutrients are scarce is still relevant (Corbella, 2008).

The photosynthetic capacity of plants under optimal environmental conditions (temperature, moisture, light) is limited only by the availability of nutrients (Barceló et al., 2001). Even in a soil well supplied with nutrients, plant nutrient uptake will be reduced if photosynthesis is restricted by other factors. Generally, the first symptoms caused by the shortage of a nutritive element are the loss of chlorophyll (chlorosis) and the disturbance of chloroplast structures. The leaves lose their characteristic green color and plant growth slows (Hernández, 1996). In this sense, $\mathrm{N}$ is the most important nutrient, due to its direct involvement in the photosynthetic process and the high levels required by plants. Phosphorus follows in importance because it is essential for energy exchange processes (Mengel and Kirkby, 2001). In a study carried out with Leucospermum cordifolium 'High Gold', Fernández-Falcón et al. (2006) found that foliar Ca concentration was positively correlated with chlorophyll activity, while the N/Ca ratio was negatively correlated with chlorophyll activity in chlorotic plants. They suggested that this could be due to nutrition imbalance associated with foliar $\mathrm{N}$ excess and low foliar Ca levels, because their ratio was higher in chlorotic plants than in healthy plants of the same plantation.

The objectives of this work were to study the soil fertility of subtropical plantations of the Leucospermum cultivars 'Succession II' and 'Tango' to assess their mineral nutrition and to investigate possible relationships between mineral nutrition and chlorophyll activity.

\section{Materials and methods}

The study was carried out over three years in commercial plantations of the Leucospermum cordifolium cultivars 'Succession II' and 'Tango'. 
The plantations were located in seven municipalities distributed around La Palma (Canary Islands), which has a subtropical climate $\left(20^{\circ} \mathrm{C}\right.$ mean annual temperature, $740 \mathrm{~mm}$ mean annual rainfall, geographical coordinates $28^{\circ} \mathrm{N} 17^{\circ} \mathrm{W}$ ). The soils were Inceptisols Andepts and an Ultisol Udult (USDA and NRCS, 2010). In tables and figures, the farms are identified with a capital $F$ followed by an ordinal number from 1 to 7 .

\section{Soil sampling and analysis}

Soil samples were collected in June 2007 and 2009 at a depth of 0 to $25 \mathrm{~cm}$ using an Eijkelkamp soil sampler. Three soil samples were taken in each of the plantations where the foliar samplings were performed. Each sample consisted of five replicates.

The samples were air-dried and passed through a 2 $\mathrm{mm}$ mesh sieve. $\mathrm{pH}$ was measured in a soil-water mixture with a ratio of 2:5, shaken and allowed to settle for 10 minutes. Organic matter was determined by the Walkley and Black method as modified by the Comisión de Métodos Analíticos del Instituto de Edafología y Agrobiología 'José M. Albareda' (1973). Available cations were extracted with a $1 \mathrm{M}$ ammonium acetate solution at $\mathrm{pH} 7$ and measured on a spectrometer (PerkinElmer ICP-OES). Available phosphorus was extracted by the Olsen et al. (1954) method and determined by the Watanabe and Olsen (1965) method. Conductivity (EC) was measured in saturated soil extract (López and López, 1990) with a Crison 503 conductimeter.

Data from the years 2007 and 2009 were combined to obtain the means for each plantation.

\section{Plant sampling and analysis}

Four foliar samplings, one every two months, were performed during the period of active growth of each cultivar, starting from the time when new leaves had reached a suitable size after the spring pruning (usually in May). Sampling was performed in 2007, 2008, and 2009. The leaves chosen for sampling were the fully developed ones closest to the apex (Benton et al., 1991), usually the $4^{\text {th }}$ or $5^{\text {th }}$ leaf. Three samples were taken from each cultivar in every plantation. Each sample consisted of leaves from 15 plants that were chosen at random.

The leaf samples were washed in distilled water and dried in an oven at $80^{\circ} \mathrm{C}$, after which they were ground to powder. One gram of the powder was ashed in an oven at $480^{\circ} \mathrm{C}$ and then mineralized by dry ashing with $6 \mathrm{M}$ hydrochloric acid (Chapman and Pratt, 1961). The levels of $\mathrm{P}, \mathrm{K}, \mathrm{Ca}, \mathrm{Mg}, \mathrm{Cu}$, $\mathrm{Fe}, \mathrm{Mn}$ and $\mathrm{Zn}$ were determined by spectroscopy (PerkinElmer ICP-OES). Nitrogen was determined by the Kjeldahl method (Cottenie, 1980).

Data from 2007, 2008 and 2009 were combined to obtain the means for each plantation.

\section{Chlorophyll activity measurements}

Chlorophyll activity measurements were taken in November 2007 with a Minolta SPAD-502 chlorophyll meter (Minolta, Japan). Five plants were randomly selected from each cultivar in each plantation, and chlorophyll measurements were performed at midday on the $4^{\text {th }}$ or $5^{\text {th }}$ leaves from the apex. The same plants were subsequently used for foliar samples because both samplings coincided in time. The chlorophyll meter gives the readings as two digits numbers which are called SPAD units.

\section{Statistical analysis}

Data were subjected to one-way analysis of variance (Tukey $\mathrm{b}$ test at $\mathrm{P}=0.05$ ), correlation, linear regression, and time series analysis by SPSS 15.0 for Windows. Time series analysis was performed by the Jonckheere-Terpstra test (Bewick, 2004) at $\mathrm{P}=0.05$. Foliar reference levels consisted of a range determined by adding and subtracting the 95th percentile to the mean of each nutrient concentration in the chosen month (September). 
Table 1. Soil chemical characteristics of the farms with the Leucospermum cordifolium cultivars 'Succession II' and 'Tango'. Means are from two years of sampling.

\begin{tabular}{|c|c|c|c|c|c|c|c|}
\hline \multirow[b]{2}{*}{ Farm } & \multirow{2}{*}{$\begin{array}{c}\mathrm{g} \mathrm{kg}^{-1} \\
\mathrm{pH}\end{array}$} & \multirow{2}{*}{$\begin{array}{c}\mathrm{mg} \mathrm{kg}^{-1} \\
\text { O.M }\end{array}$} & \multicolumn{3}{|c|}{$\mathrm{cmol} \mathrm{kg}^{-1}$} & \multirow[b]{2}{*}{$\mathrm{K}$} & \multirow{2}{*}{$\begin{array}{c}\mathrm{dS} \mathrm{m}^{-1} \\
\text { E.C. }\end{array}$} \\
\hline & & & $\mathrm{P}$ & $\mathrm{Ca}$ & $\mathrm{Mg}$ & & \\
\hline F1 & $5.58 \mathrm{a}^{1}$ & $28.8 \mathrm{~b}$ & $59 \mathrm{a}$ & $3.76 \mathrm{~b}$ & $2.63 \mathrm{ab}$ & 1.42 & $0.93 \mathrm{ab}$ \\
\hline $\mathrm{F} 2$ & $5.66 \mathrm{a}$ & $44.7 \mathrm{~b}$ & $27 \mathrm{~b}$ & $10.01 \mathrm{a}$ & $3.38 \mathrm{ab}$ & 1.6 & $1.12 \mathrm{a}$ \\
\hline F3 & $5.90 \mathrm{a}$ & $85.8 \mathrm{a}$ & $6 \mathrm{e}$ & $4.30 \mathrm{~b}$ & $1.92 \mathrm{~b}$ & 0.98 & $0.50 \mathrm{~cd}$ \\
\hline F4 & $6.09 \mathrm{a}$ & $52.2 \mathrm{~b}$ & $15 \mathrm{bc}$ & $8.79 \mathrm{a}$ & $5.19 \mathrm{a}$ & 1.54 & $0.62 \mathrm{bc}$ \\
\hline F5 & $4.99 \mathrm{~b}$ & $43.3 \mathrm{~b}$ & $21 \mathrm{bc}$ & $2.74 \mathrm{~b}$ & $1.51 \mathrm{~b}$ & 1.81 & $0.46 \mathrm{~d}$ \\
\hline F6 & $6.05 \mathrm{a}$ & $25.3 \mathrm{~b}$ & $11 \mathrm{~cd}$ & $9.69 \mathrm{a}$ & $4.68 \mathrm{ab}$ & 1.94 & $1.00 \mathrm{ab}$ \\
\hline F7 & $6.02 \mathrm{a}$ & $45.4 \mathrm{~b}$ & $13 \mathrm{~cd}$ & $11.96 \mathrm{a}$ & $3.43 \mathrm{ab}$ & 1.02 & $0.70 \mathrm{bc}$ \\
\hline
\end{tabular}

${ }^{1}$ Means followed by different letters are significantly different according to the Tukey $b$ test $(\mathrm{p}=0.05)$.

\section{Results and discussion}

\section{Soils}

One of the soils had a very acidic $\mathrm{pH}$; of the remaining soils, half were acidic, and the other half were slightly acidic (Table 1). A slightly acidic $\mathrm{pH}$ is most favorable to Proteaceae (Hernández et al., 2008).

The organic matter content was within an acceptable range, though in one plantation it was excessive (higher than $70 \mathrm{~g} \mathrm{~kg}^{-1}$ ) as defined by Piqué et al. (1996).

Concentrations of available P in two soils (27 and $59 \mathrm{mg} \mathrm{kg}^{-1}$ ) exceeded those recommended by Parvin (1986). One soil was found to have deficient $\mathrm{P}\left(6 \mathrm{mg} \mathrm{kg}^{-1}\right)$, and the remaining soils had acceptable P levels.

Most soils had Ca levels within the values suggested by Jamienson (1985), but Ca represented $60 \%$ or more of the total cations in some plantations, indicating possible nutritional imbalances with other cations (Porta et al., 2003).

Available Mg concentrations were high as defined by Jamienson (1985), and the ratio of $\mathrm{Mg}$ to $\mathrm{Ca}$ was acceptable in most soils.

Potassium concentrations were high compared to those reported by Jamienson (1985), except in one plantation that had a moderate value $\left(0.98 \mathrm{cmol}_{(+)} \mathrm{kg}^{-1}\right)$. The ratio of $\mathrm{K}$ to $\mathrm{Ca}$ was acceptable in most soils. Potassium followed the same trend as available $\mathrm{Mg}$ in relation to the sum of cations.

No salinity danger was evident from the electrical conductivities determined in the soils of all the plantations.

Chlorophyll activity (SPAD units) of the studied

\section{Leucospermum cultivars}

Chlorophyll activity in SPAD units (Figure 1) ranged between 49 and 67 in 'Succession II' and between 50 and 59 in 'Tango'. These data neither correlated with the concentrations of the studied nutrients nor fit the field observations. SPAD units and foliar N levels have been shown to relate to each other (Neilsen et al., 1995), but the lack of a relationship in this case could be due to the good N nutrition of the plants; in most cases, the studied plants had similar $\mathrm{N}$ levels, as will be discussed later. Only the $\mathrm{Ca} / \mathrm{K}$ ratio showed a positive correlation with the SPAD units (Figure 2), though no satisfactory explanation was found for this. In Leucospermum cordifolium 'High Gold', Fernández-Falcón et al. (2006) observed a relationship between SPAD units and $\mathrm{Ca}$; however, their findings were related to foliar chlorosis, which was not observed in this assay. 


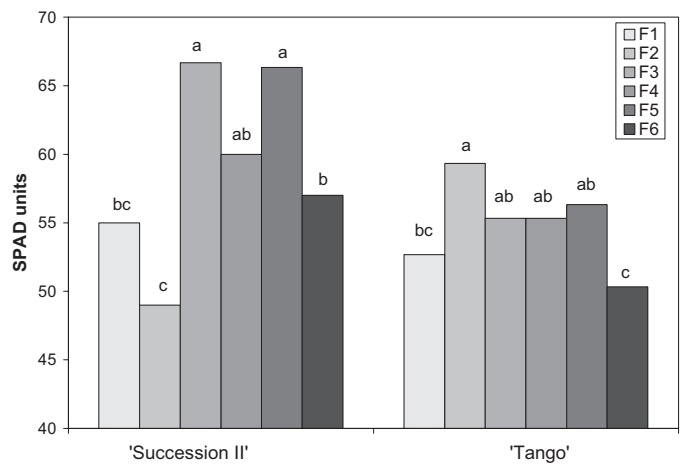

Figure 1. Chlorophyll activity, measured in SPAD units, of the leaves of the cultivars 'Succession II' and 'Tango'. A one-way Tukey $b$ test was used to test differences between plantation means. Different letters on the columns of the same cultivar denote significant differences at $\mathrm{P}=0.05$. Data are from 2007.

In the cultivar 'Succession II', significantly different SPAD units, ranging from low (55) to high (66 to 67), were observed in plants that had slight leaf chlorosis. Plants with normal green leaves were also observed to have significantly different SPAD units, ranging from low (49) to high (60). In the cultivar 'Tango', slightly yellowing leaves presented average quantities of chlorophyll (53 to 56 SPAD units), and plants with normal leaves gave significantly different readings ranging from low to high SPAD limits.

These results conflict with those observed by Fernández-Falcón et al. (2006), who found that low SPAD units were associated with chlorosis and nutrient imbalances in the L. cordifolium cultivar 'High Gold'. This suggests that the relationship between these symptoms and chlorophyll activity as measured by SPAD differs depending upon the cultivar. However, it could also be that the chlorosis was too slight for SPAD to measure any differences.

Because the SPAD measurements showed no correlation with metrics of plant nutrition (except for the already mentioned $\mathrm{Ca} / \mathrm{K}$ ratio) or foliar greenness in the cultivars 'Succession II' and 'Tango', SPAD measurements were discontinued in 2008 and 2009.

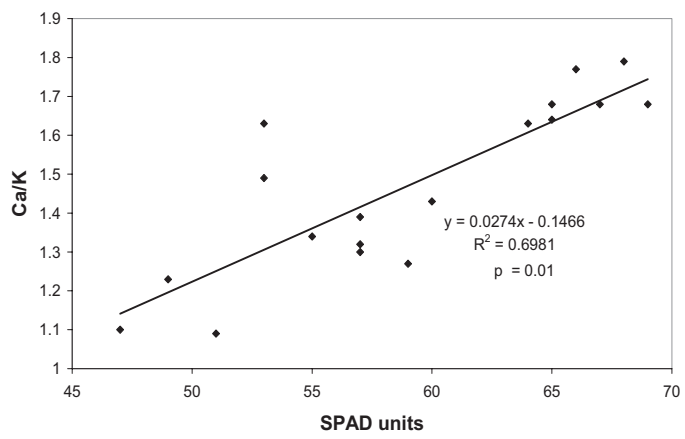

Figure 2. Regression equation, probability level and tendency line for chlorophyll activity (measured as SPAD units) versus leaf $\mathrm{Ca} / \mathrm{Mg}$ ratio. Linear regression was carried out by SPSS 15.0 for Windows. Data are from 2007.

\section{Plant nutrition}

The results discussed here are the averages of the data from 2007, 2008, and 2009.

Foliar $N, P$ and $K$ contents. The nitrogen means ranged between 6.0 and $13.5 \mathrm{~g} \mathrm{~kg}^{-1}$ in the cultivar 'Succession II' and between 7.1 and $17.2 \mathrm{~g} \mathrm{~kg}^{-1}$ in 'Tango' (Figure 3). Most plantations of both cultivars had similar $\mathrm{N}$ levels in each sampling, which could explain the lack of relationship with SPAD chlorophyll measurements. These observations encompassed the mean $\left(11 \mathrm{~g} \mathrm{~kg}^{-1}\right)$ determined by Parvin (1986) for L. cordifolium. The highest $\mathrm{N}$ value in 'Tango' exceeded the upper limits ( 9.1 to $13.4 \mathrm{~g} \mathrm{~kg}^{-1}$ ) obtained by Hernández et al. (2008) in several L. cordifolium cultivars. It must be taken into account that these plants do not receive $\mathrm{N}$ fertilizers, and their $\mathrm{N}$ supply depends only upon the mineralization of organic matter.

Phosphorus showed means of 0.32 to $1.30 \mathrm{~g} \mathrm{~kg}^{-1}$ in 'Succession II' and 0.45 to $0.96 \mathrm{~g} \mathrm{~kg}^{-1}$ in 'Tango' (Figure 4). All the samplings of 'Succession II' and most of 'Tango' showed significant differences among plantations. The mean reported by Parvin (1986) for L. cordifolium was higher than this, as was the lower limit of the range ( 0.8 to $1.3 \mathrm{~g} \mathrm{~kg}^{-1}$ ) found by Hernández et al. (2008) in 

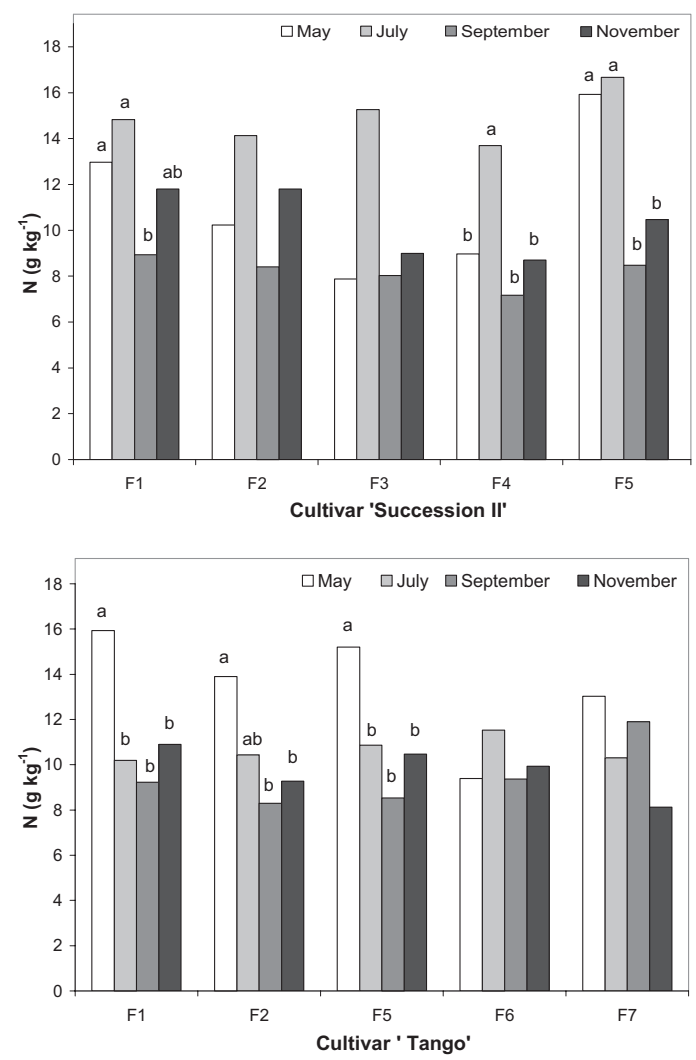

Figure 3. Nitrogen content of the leaves over time (means of the three years of the assay) of the Leucospermum cultivars in each plantation. Analysis of significant differences in the time series was performed by the Jonckheere-Terpstra test $(\mathrm{P}=0.05)$. Top: Data for 'Succession II' cultivar. Bottom: Data for 'Tango' cultivar.

several L. cordifolium cultivars. Even higher intervals $\left(0.5\right.$ to $\left.3.2 \mathrm{~g} \mathrm{~kg}^{-1}\right)$ were reported by several authors (Nichols, 1988; Creswell, 1991; Maier et al., 1995; Haigh et al., 1997) for Protea. Ran et al. (2001) reported a range between 0.6 and $1.2 \mathrm{~g}$ $\mathrm{kg}^{-1}$. Though the measured $\mathrm{P}$ concentrations were comparatively low, the plants yielded abundant flowers of good commercial quality, which points to the low $P$ requirements of these cultivars. Average foliar P levels in the plantations with lower soil P content (farms F3, F6 and F7) could be related to the formation of proteoid roots that enhance $\mathrm{P}$ uptake from soil (Shane et al., 2008; Hue, 2009).

K means of 'Succession II' ranged from 1.4 to $7.49 \mathrm{~g} \mathrm{~kg}^{-1}$, while those of 'Tango' were between 2.0 and $4.9 \mathrm{~g} \mathrm{~kg}^{-1}$ (Figure 5). In most cases, the
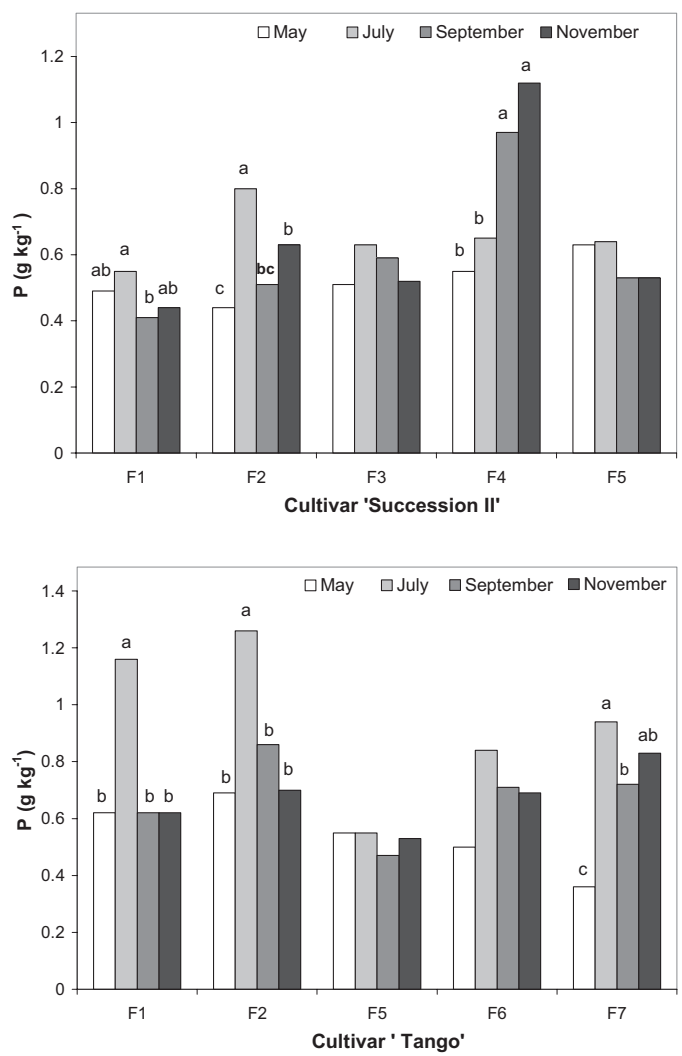

Figure 4. Phosphorus content of the leaves over time (means of the three years of the assay) of the Leucospermum cultivars in each plantation. Analysis of significant differences in the time series was performed by the Jonckheere-Terpstra test $(\mathrm{P}=0.05)$. Top: Data for 'Succession II' cultivar. Bottom: Data for 'Tango' cultivar.

different plantations of each cultivar had different foliar K levels. Parvin (1986) reported a mean of $4.4 \mathrm{~g} \mathrm{~kg}^{-1}$ in Leucospermum cordifolium, and Hernández et al. (2008) reported a range from 4.1 to $7.6 \mathrm{~g} \mathrm{~kg}^{-1}$ that exceeded the range of 'Tango' observed in this study. It is important to highlight that despite the fact that the $\mathrm{K}$ content was high in the soil of both cultivars, 'Tango' showed lower levels of foliar K than 'Succession II'. This supports the idea that nutrition in Proteaceae may differ within the same genus, the same species and even within cultivars of the same species (Claassens, 1986; Montarone et al., 2003; Hernández et al., 2008).

Correlations. Few correlations were found between different nutrients. Leaves of both cultivars showed 

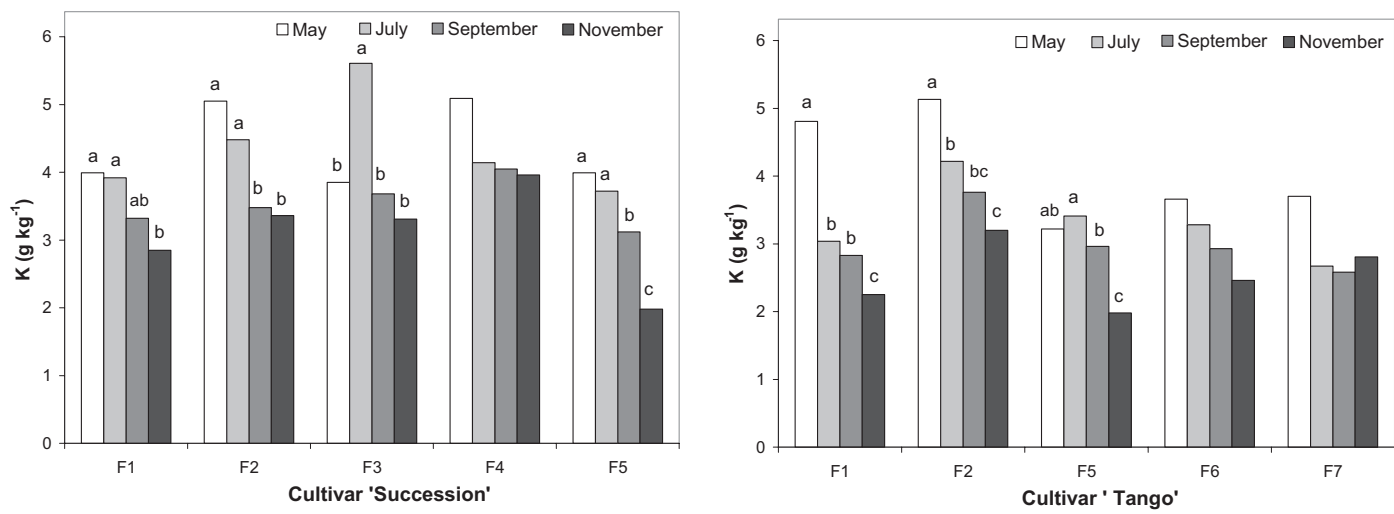

Figure 5. Potassium content of the leaves over time (means of the three years of the assay) of the Leucospermum cultivars in each plantation. Analysis of significant differences in the time series was performed by the Jonckheere-Terpstra test (P $=0.05)$. Left: Data for 'Succession II' cultivar. Right: Data for 'Tango' cultivar.

positive relationships between the $\mathrm{K} / \mathrm{Mg}$ ratio and $\mathrm{Ca}(\mathrm{r}=0.536, \mathrm{P}=0.001$ and $\mathrm{r}=0.530, \mathrm{P}=0.001$ for 'Succession II' and 'Tango', respectively). Another positive correlation $(\mathrm{r}=0.501, \mathrm{P}=0.001)$ between the $\mathrm{N} / \mathrm{Ca}$ ratio and $\mathrm{Mg}$ appeared only in 'Tango'. It is known that uptake of $\mathrm{Mg}$ and $\mathrm{Ca}$ can be greatly depressed by an excess of other cation species, especially $\mathrm{K}$ and $\mathrm{NH}_{4}$, which are taken up at high rates and may compete with $\mathrm{Mg}$ and $\mathrm{Ca}$ for the negatively charged cytosol. The translocation of $\mathrm{Mg}$ from the roots to the upper plant parts can be restricted by $\mathrm{K}$ and $\mathrm{Ca}$ (Mengel and Kirkby, 2001). In spite of these theoretical negative relationships, Ca showed a positive relationship with $\mathrm{Mg}$ in both cultivars (Figures 6 and 7). A similar correlation was observed by Barroso (1989) in strawberries and

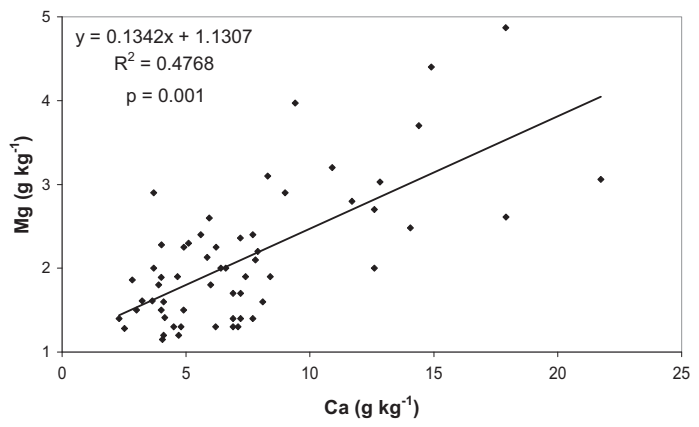

Figure 6. Regression equation, probability level and tendency line for foliar $\mathrm{Ca}$ and $\mathrm{Mg}$ in the cultivar 'Succession II'. Linear regression was carried out with SPSS 15.0 for Windows. Data are from 2008 and 2009. by Amin (2002) in potatoes. Broadley et al. (2008) reported an analogous behavior of $\mathrm{Ca}$ and $\mathrm{Mg}$ in wild cabbage that they attributed to the chemical similarity of these ions. This contradiction may indicate that $\mathrm{N}$ and $\mathrm{K}$ play a role in the nutrition of $\mathrm{Ca}$ and $\mathrm{Mg}$ in these Leucospermum cultivars that cannot be described by direct correlations among these nutrients.

No additional correlations were observed among nutrients, nutrient ratios or soil properties.

Evolution of plant nutrition over time. The consistency of nutrient concentrations between samples can be used to decide which is the best month to take standard foliar samples (Benton et al., 1991).

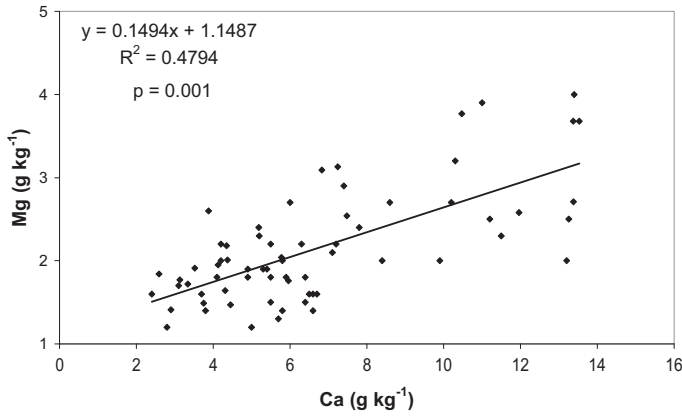

Figure 7. Regression equation, probability level and tendency line for foliar $\mathrm{Ca}$ and $\mathrm{Mg}$ in the cultivar 'Tango'. Linear regression was carried out with SPSS 15.0 for Windows. Data are from 2008 and 2009. 
Foliar N did not experience significant changes over time in three of the plantations of 'Succession II' and three of 'Tango' (Figure 3). In the 'Succession II' plantations that did show differences, the maximum value appeared in May in one case and in November in another. In two plantations of 'Tango', the concentrations were higher in the May sampling, then showed a significant decline in July and maintained a similar value during September and November. Values stabilized in July and September in one plantation of 'Succession' and three of 'Tango'.

Two plantations of 'Succession II' and one of 'Tango' had similar foliar P concentrations across all four sampling months (Figure 4). In two cases, a significant maximum of $\mathrm{P}$ in 'Succession II' was observed in May; a similar pattern was observed for 'Tango'. In one plantation, both cultivars showed maxima in July, then the P concentrations decreased and remained steady throughout September and November. Seven plantations, including both cultivars, showed similar foliar levels of $\mathrm{P}$ in September and November. Hernández et al. (2008) observed also a stabilization of foliar $\mathrm{P}$ levels between September and November in some L. cordifolium cultivars.

In general, the evolution of foliar $\mathrm{K}$ followed similar patterns in 'Succession' and 'Tango': the highest values were observed in May in most of the plantations, and they decreased in July and remained stable in September (Figure 5). The higher concentrations of $\mathrm{K}$ in spring may point to a need for plants to increase their $\mathrm{K}$ content to recover from late winter pruning and enable the development of new buds.
Foliar standard. As discussed in the previous section, apart from the plantations in which there were no significant differences among the different sampling months, a stabilization of the studied nutrients was observed between the months of July and September or September and November (although the values of some nutrients were consistent across all three sampling points). September generally showed the greatest stability of N, P and K values, so it was chosen as the most suitable month in which to measure nutrient leaf standards of the studied cultivars. This conflicts with the findings of Hernández et al. (2008), who reported that November was the optimal month in which to take standard samples of other $L$. cordifolium cultivars.

Nitrogen. The standard range of foliar $\mathrm{N}$ in 'Succession II' was wider than in 'Tango', and the maximum of 'Succession II' exceeded by 2.07 $\mathrm{g} \mathrm{kg}^{-1}$ that of 'Tango' (Table 2). These bottom limits are lower than those found by Hernández et al. (2008) in different L. cordifolium cultivars. In several plants of the genus Protea, Haigh et al. (1997) detected 3.5 to $28.3 \mathrm{~g} \mathrm{~kg}^{-1}$ of foliar $\mathrm{N}$, while Ran et al. (2001) observed between 15 and $20 \mathrm{~g} \mathrm{~kg}^{-1}$ in Leucadendron.

Phosphorus. The standard range of foliar P was very similar between the two cultivars. Hernández et al. (2008) reported upper and lower limits in some $L$. cordifolium cultivars that were higher than those found in the present study. Haigh et al. (1997) reported levels of 0.5 to $3.2 \mathrm{~g} \mathrm{~kg}^{-1}$ in Protea, and Ran et al. (2001) measured levels of 0.6 to $1.2 \mathrm{~g} \mathrm{~kg}^{-1}$ in Leucadendron.

Table 2. Foliar macronutrient standard ranges of Leucospermum cordifolium cultivars 'Succession II' and 'Tango'. Data are from three years of sampling.

\begin{tabular}{lccccc}
\hline & \multicolumn{5}{c}{$\mathrm{g} \mathrm{kg}^{-1}$} \\
\cline { 2 - 6 } Cultivar & $\mathrm{N}$ & $\mathrm{P}$ & $\mathrm{K}$ & $\mathrm{Ca}$ & $\mathrm{Mg}$ \\
\hline Succession II & $4.44-15.10$ & $0.23-0.89$ & $2.76-4.72$ & $1.29-9.67$ & $0.74-3.60$ \\
Tango & $5.27-13.03$ & $0.24-0.92$ & $3.00-3.72$ & $1.52-8.26$ & $1.48-2.74$ \\
\hline
\end{tabular}


Potassium. The upper limit of foliar K in 'Succession II' exceeded that of 'Tango' by $21 \%$ (Table 2). These results show ranges lower than those given by Hernández et al. (2008) in Leucospermum cordifolium cultivars. Haigh et al. (1997) observed foliar K levels of 1.8 to $4.1 \mathrm{~g} \mathrm{~kg}^{-1}$ in Protea, and Ran et al. (2001) reported 5 to $8 \mathrm{~g}$ $\mathrm{kg}^{-1}$ in Leucadendron.

Calcium. The standard values of foliar Ca for both cultivars behaved similarly to the standard values of N (Table 2). Generally, these values were lower than those observed by Hernández et al. (2008) in other Leucospermum cordifolium cultivars. In Leucadendron, Cecil et al. (1995) obtained values of 2.4 to $3.9 \mathrm{~g} \mathrm{~kg}^{-1}$.

Magnesium. The standard ranges of foliar $\mathrm{Mg}$ behaved similarly to those of $\mathrm{N}$ and $\mathrm{Ca}$ (Table 2). They were lower than those measured by Hernández et al. (2008) in some Leucospermum cordifolium cultivars. Haigh et al. (1997) found a range from 1.0 to $4.0 \mathrm{~g} \mathrm{~kg}^{-1}$ in Protea, and Cecil et al. (1995) observed a range from 1.6 to $2.5 \mathrm{~g}$ $\mathrm{kg}^{-1}$ in Leucadendron.

Copper. The most notable feature of $\mathrm{Cu}$ was that in both cultivars, the lowest level of the standard interval was $0.2 \mathrm{~m} \mathrm{~kg}^{-1}$, while the maximum level of 'Succession II' exceeded that of 'Tango' by $0.7 \mathrm{mg} \mathrm{kg}^{-1}$ (Table 3). The intervals reported by Fernández-Falcón et al. (2008) for some cultivars of Leucospermum cordifolium showed a higher bottom limit but a narrower range overall.

Iron. The cultivar 'Tango' showed a wider range of foliar Fe, with an upper limit $16.0 \mathrm{mg} \mathrm{kg}^{-1}$ greater than that of 'Succession II' (Table 3).
These limits were lower than those determined by Fernández-Falcón et al. (2008) for other cultivars of L. cordifolium. The interval (15 to $170 \mathrm{mg}$ $\mathrm{kg}^{-1}$ ) observed by Haigh et al. (1997) in Protea, encompassed the interval (50 to $80 \mathrm{mg} \mathrm{kg}^{-1}$ ) found by Ran et al. (2001) in Leucadendron.

Manganese. The bottom limit of the Mn standard range for the cultivar 'Tango' was $4 \mathrm{mg} \mathrm{kg}^{-1}$ lower than that of 'Succession II'. However, the upper limit of 'Tango' exceeded that of 'Succession II' by $63 \%$ (Table 3 ). In some cultivars of Leucospermum cordifolium, Fernández-Falcón et al. (2008) obtained narrower but higher intervals than those observed in this study. The range of standard values (120 to $500 \mathrm{mg} \mathrm{kg}^{-1}$ ) reported for Protea by (Haigh et al., 1997) included the values for Leucadendron reported by Ran et al. (2001).

Zinc. Foliar standard levels of $\mathrm{Zn}$ showed the highest upper limits in 'Tango' (Table 3). FernándezFalcón et al. (2008) observed lower ranges in other Leucospermum cordifolium cultivars. Haigh et al. (1997) detected 10 to $60 \mathrm{mg} \mathrm{kg}^{-1}$ in Protea, while Cecil et al. (1995) measured 11 to $25 \mathrm{mg}$ $\mathrm{kg}^{-1}$ in Leucadendron.

Although the studied L. cordifolium cultivars did not receive $\mathrm{N}$ fertilizers and although their $\mathrm{N}$ supply depended only upon the organic matter mineralization, they showed normal $\mathrm{N}$ nutrition and good yields. Despite the fact that some soils contained high amounts of $\mathrm{P}$, the plants grew well in them, showing that some Leucospermum are not as $\mathrm{P}$ sensitive as is often reported. The soils of both cultivars were high in K, but the foliar K of 'Tango' was lower than that of 'Succession II', indicating that nutri-

Table 3. Foliar micronutrient standard ranges of Leucospermum cordifolium cultivars 'Succession II' and 'Tango'. Data are from three years of sampling.

\begin{tabular}{ccccc}
\hline & \multicolumn{4}{c}{$\mathrm{mg} \mathrm{kg}^{-1}$} \\
\cline { 2 - 5 } Cultivar & $\mathrm{Cu}$ & $\mathrm{Fe}$ & $\mathrm{Mn}$ & $\mathrm{Zn}$ \\
\hline Succession II & $0.2-13.7$ & $13.4-48.6$ & $21-345$ & $6.2-30.2$ \\
Tango & $0.2-13.0$ & $10.8-64.6$ & $17-543$ & $7.6-35.8$ \\
\hline
\end{tabular}


tion of Leucospermum may even differ within cultivars of the same species. The study of the stability of the concentrations of foliar N, P and $\mathrm{K}$ throughout time showed that the month of September was most suitable for determining the standard levels of foliar nutrients. The standard ranges showed wide variation for the nutrients $\mathrm{N}, \mathrm{Ca}, \mathrm{Cu}, \mathrm{Fe}, \mathrm{Mn}$ and $\mathrm{Zn}$, while the ranges of $\mathrm{Mg}, \mathrm{P}$ and $\mathrm{K}$ were more restricted.

\section{Acknowledgements}

The authors acknowledge funding received from the Excelentísimo Cabildo Insular de La Palma and the Consejo Superior de Investigaciones Científicas. We also acknowledge Proteas de la Palma Sociedad Cooperativa for their logistical support and the collaboration of their staff, without whom this work could not have been carried out.

\section{Resumen}

C.E. Álvarez, M. Fernández-Falcón y M.M. Hernández. 2012. Nutrición mineral, estándares foliares, actividad clorofílica y estado de los nutrientes de los suelos de dos cultivares de protea Leucospermum cordifolium (Proteaceae). Cien. Inv. Agr. 39(1): 105-116. Se estudiaron dos cultivares de protea ('Succession II' y 'Tango') de Leucospermum cordifolium, durante tres años, en plantaciones comerciales con rendimientos óptimos situadas in la isla de La Palma (Archipiélago Canario) con clima subtropical. Se realizaron cuatro muestreos anuales durante su ciclo vegetativo para conocer la evolución de sus contenidos de N, P y K con el tiempo, y el mejor mes para realizar el muestreo foliar estándar. Se determinaron las concentraciones foliares estándar de macro y micronutrients así como la actividad clorofílica. También se tomaron muestras de suelo. Ambos cultivares se desarrollaron bien en suelos ácidos y neutros, con contenidos altos y bajos de material orgánica, y algunos con elevada concentración de $\mathrm{P}$ asimilable, al que las proteas son sensibles. La actividad clorofílica no se correlacionó con los niveles de nutrientes foliares ni con el verdor de las hojas. El máximo contenido foliar de $\mathrm{N}$ alcanzó 17,0 $\mathrm{g} \mathrm{kg}^{-1}$ en el cultivar 'Succession II' y 17,2 $\mathrm{g} \mathrm{kg}^{-1}$ in 'Tango', mientras que los máximos de $\mathrm{P}$ y K fueron menores en 'Tango'. El muestreo de Septiembre mostró la mayor estabilidad de estos nutrientes, por lo que este mes se escogió para realizar el muestreo foliar estándar. Los intervalos estándares de N, K, Ca y Mg fueron superiores en 'Succession II', mientras que lo contrario sucedió con el Fe, Mn y Zn. Por otra parte, los de P y $\mathrm{Cu}$ fueron similares en ambos cultivares.

Palabras clave: Análisis foliar, protea, 'Succession II', 'Tango'.

\section{References}

Amin, M. 2002. Estudio del efecto de abonos orgánicos y de síntesis sobre la fertilidad de los suelos, lixiviación de nutrientes, nutrición mineral de la papa (Solanum tuberosum L. cvs. 'Cara'), producción y características físico-químicas de sus tubérculos. Ph. D. Thesis. Universidad de la Laguna, Spain. 275 pp.

Barceló, J., G. Nicolás, B. Sabater, and R. Sánchez. 2001. Fisiología Vegetal. Ediciones Pirámide, S.A., Madrid, Spain. 556 pp.
Barroso, M.C. 1989. Efecto de la salinidad en el crecimiento, producción y nutrición mineral de la planta de fresa. Ph. D. Thesis. Universidad de La Laguna, Spain. 236 pp.

Benton, J., B. Wolf, and H.A. Mills. 1991. Plant Analysis Handbook. Micro-Macro Publishing, Inc., Athens, USA. 123 pp.

Bewick, V., L. Cheek, and J. Ball. 2004. Statistic review 10: Further non parametric methods. Critical Care 8:196-199.

Broadley, M.R., J.P. Hammond, G.J. King, D. Astley, H.C. Bowen, M.C. Meacham, A. Mead, D.A.C. 
Pink, G.R. Teakle, R.M. Hayden, W.P. Spracklen, and P.J. White. 2008. Shoot calcium (Ca) and magnesium $(\mathrm{Mg})$ concentrations differ between subtaxa, are highly heritable, and associate with potentially pleiotropic loci in Brassica oleracea. Plant Physiology 146: 1707-1720.

Buining, F., and G. Cresswell. 1993. Working party on nutrition Proteaceae. Journal of the International Protea Association 26:21-27.

Claassens, A.S. 1981. Soil preparation and fertilization of proteas. Farming in South Africa, Series: Flower, Ornamental Shrubs and Trees, Department of Agriculture and Fisheries, Pretoria, South Africa, B. 14.

Claassens, A.S. 1986. Some aspects of the nutrition of proteas. Acta Horticulturae 185: 171-179.

Cecil, J.S., G.E. Barth, N.A. Maier, W.L. Chvyl, and M.N. Bartetzko. 1995. Leaf chemical composition and nutrient removal by stems of Leucadendron cvs. Silvan Red and Safari Sunset. Australian Journal of Experimental Agriculture 35:547-555.

Chapman, H. D., and P.F. Pratt. 1961. Methods of analysis for soils, plants and waters. University of California, Division of Agricultural Sciences, Berkeley, USA. 309 pp.

Comisión de Métodos Analíticos del Instituto de Edafología y Agrobiología 'José María Albareda'. 1973. Determinaciones analíticas en suelos. Normalización de métodos: $\mathrm{pH}$, materia orgánica y nitrógeno. Anales de Edafología y Agrobiología 32:1153-1172.

Corbella, M. 2008. Efecto de la concentración de fósforo en un cultivo hidropónico de Leucospermum cordifolium 'Flame Spike'. Tesis Doctoral. Universidad de La Laguna, La Laguna, España. 270 pp.

Cottenie, A. 1980. Soil and plant testing as a basis of fertilizer recommendations. FAO Soils Bulletin, $38 / 2$, Rome.

Cresswell, C. 1991. Assessing the phosphorus status of Proteas using plant analysis. In $6^{\text {th }}$ Biennial International Protea Association Conference. Page 303-310. Perth, Western Australia.

Fernández-Falcón, M., M. Hernández, C.E. Alvarez, and A.A. Borges. 2006. Evolution of nutrition and chlorophyll content of Leucospermun cor- difolium cv. 'High Gold', and their relationship with chlorotic sypmptoms. Scientia Horticulturae 107:373-379.

Fernández-Falcón, M., C.E. Alvarez, and M. Hernández, M. 2008. Nutrient removal, fertilization, needs and yields of Protea plants cultivated in subtropical conditions. Journal of Plant Nutrition 31:1018-1032.

González, A.C.E., M. Hernández, and M. FernándezFalcón. 2008. Nutrient distribution and stem length in flowering stems of Protea Plants. Journal of Plant Nutrition 31:1624-1641.

Haigh, A., S.E. Parks, and G.C. Cresswell. 1997. A Guide to nutritional requirements of some Proteaceae. RIRDC Research Paper Series $\mathrm{N}^{\circ} 97 / 38$

Handreck, K.A. 1991. Interactions between iron and phophorus in the nutrition of Banksia ericifolia $\mathrm{L}$. f. var. ericifolia (Proteaceae) in soil-less potting media. Australian Journal of Botany 39: 373-384.

Hernández, E.M. 1996. Relación entre la nutrición mineral de plantas de papa (Solamum tuberosum cv. Cara) y su contenido en clorofila, estimado con el medidor de clorofila SPAD-502 de Minolta. Tesis de Graduación, Universidad de La Laguna, Spain. 125 pp.

Hernández, M., M. Fernández-Falcón, and C.E. Alvarez. 2008. Study of soil fertility and plant nutrition of proteas cultivated under subtropical conditions. Communications in Soil Science and Plant Analysis 39:2146-2168.

Hue, N.V. 2009. Iron and phosphorus fertilization and the development of proteoid roots in macadamia (Macadamia integrifolia). Plant and Soil 318: 93-100.

Jamienson, A.C. 1985. Proteaceae flower and foliage production. N.Z. Ministry of Agriculture and Fisheries. Aglink Hpp 106:1-4.

López, R.J., and M.J. López. 1990. El diagnóstico de suelos y plantas. Editorial Mundi-Prensa, Madrid, Spain. 363 pp.

Maier, N.A., C.E. Barth, J.S. Cecil, W.L. Chvyl, and M.N Bartetzko, 1995. Effect of sampling time and leaf position on leaf nutrient composition of Protea 'Pink Ice'. Australian Journal of Experimental Agriculture 35:275-283. 
Mengel, L.K., and E.H. Kirkby. 2001. Principles of Plant Nutrition. Kluwer Academic Publishers, Boston, USA. 849 pp.

Montarone, M., and M. Ziegler. 1996. Water and mineral absorption by two Protea species (P. eximia and P. cynaroides) according to their development stage. Acta Horticulturae 453:135-144.

Montarone, M. 2001. Update on the cultivation of protea. Acta Horticulturae 545:127-133.

Montarone, M., M. Ziegler, N. Dridi, and S. Voisin. 2003. Comparison of mineral requirements of some cultivars in two proteaceae genera. International Protea News 44:103-111.

Nichols, D. 1983. The phosphorus nutrition of proteas. In: Growing and Marketing of Proteas. Volume 1. Proteaflora Enterprises, Melbourne, Australia. p. 84-99.

Nichols, D. 1988. The nutrition of proteas. Journal of the International Protea Association 15:16-18.

Neilsen, D., E.J. Hogue, G.H. Neilsen, and P. Parchomchuk. 1995. Using SPAD-502 values to asses the nitrogen status of trees. HortScience.30:508-512.

Olsen, S.R., C.V. Cole, F.S. Watanabe, and L.A. Dean. 1954. Estimation of available phosphorus in soils by extraction with sodium bicarbonate. United States Department of Agriculture, Circular 939 .

Parvin, P.E. 1986. Use of tissue and soil samples to establish nutritional standards in protea. Acta Horticulturae 185:145-153.

Piqué, E., C.E. Alvarez, and M. Fernández.1996. Micronutrients in soils and plants from organic farms of Tenerife (Canary Islands). Biological Agriculture and Horticulture 13:113-122.

Porta, J., M. López-Acevedo, and C. Roquero. 2003. Edafología para la agricultura y el medio ambiente. Ediciones Mundi-Prensa, Madrid, Spain. 960 pp.

Prasad, M., and D.J. Dennis. 1986. Phosphorus Nutrition of Leucadendron "Safari Sunset". Acta Horticulturae 185:155-162.
Price, G.H. 1986. Ornamentals. In: D.J. Reuter and J.B. Robinson (eds.). Plant Analysis: an Interpretation Manual. Pages 188-217. Inkata Press, Melbourne, Sydney, Australia.

Ran, I., H. Hupert, A. Avidan, M. Eizinger, and E. Shlomo. 2001. Leaf analysis as a tool for determination of proper fertilization of Leucadendron 'Safari Sunset'. Acta Horticulturae 545:145-154.

Rodríguez Pérez, J. A., M. Fernández-Falcón, and A.R. Socorro-Monzón. 2001. The effect of salinity on growth and nutrition of Leucospermum cordifolium. Journal of Horticultural Science and biotechnology 76:601-607.

Shane, M.W., M.D. Cramer, and H. Lambers. 2008. Root of edaphically controlled Proteacea turnover on the Angulha Plain, South Africa: phosphate uptake regulation and growth. Plant, Cell and Environment 31:1825-1833.

Silber, A., R. Ganmore-Neumann, and J. Ben-Jaacov. 1998. Effects of nutrient addition on growth and rhizosphere $\mathrm{pH}$ of Leucadendron 'Safari Sunset'. Plant and Soil 199: 205-211.

Thomas, M.B. 1980. Phosphorus response of Proteaceae and other nursery plants in containers. Royal New Zealand Institute of Horticulture Annual Journal 8, 21-33

USDA (United States Department of Agriculture) and NRCS (Natural Resources Conservation Science). 2010. Keys to soil taxonomy. Washington. p. 346.

Watanabe, F.E., and S.R. Olsen. 1965. Test of an ascorbic acid method for determining phosphorus in waters and sodium bicarbonate extract from soil. Soil Science of America Proceedings 29:667-668.

Witkowski, E.T.F. 1989. Effects of nutrients on the distribution of dry mass, nitrogen and phosphorus in seedlings of Protea repens (L.) (Proteaceae). New Phytologist 112: 481-487. 